\title{
Teeth of the Renaissance: A paleopathological and historic-medical study on the jaws of the Medici Family
}

\author{
Stefano Colagrande ${ }^{\mathrm{a}, *}$, Natale Villari ${ }^{\mathrm{a}}$, Felicita Pierleoni ${ }^{\mathrm{b}}$, Domizia Weber $^{\mathrm{c}}$, \\ Gino Fornaciari ${ }^{\mathrm{d}}$, Donatella Lippi ${ }^{\mathrm{c}}$ \\ ${ }^{a}$ University of Florence, Department of Experimental and Clinical Biomedical Sciences, Radiodiagnostic Unit n. 2, Azienda Ospedaliero-Universitaria Careggi, \\ Largo Brambilla 3, Florence 50134, Italy \\ ${ }^{\mathrm{b}}$ University of Florence, Department of Public Health, Azienda Ospedaliero-Universitaria Careggi, Italy \\ ${ }^{\mathrm{c}}$ University of Florence, Department of Experimental and Clinical Medicine, History of Medicine, Italy \\ d University of Pisa, Department of Translational Research on New Technologies in Medicine and Surgery, Division of Paleopathology Italy
}

\section{A R T I C L E I N F O}

\section{Article history:}

Received 7 June 2013

Received in revised form

10 July 2013

Accepted 29 July 2013

Available online 8 August 2013

\section{Keywords:}

Medici Family

Paleopathology

Florence Renaissance

Hasburg jaw

Dental hygiene

Dental lesion index

Fluorosis

History of dentistry

Historic-medical studies

Dental imaging studies

\begin{abstract}
A B S T R A C T
Objectives: Aim of this study is to present the radiological assessment of the dental pathologies in the Medici Family, to supply evidence of their oral diseases and to verify the efficacy of hygiene methods of the time, providing a term of comparison for other cases.

Methods: The Medici Project is a paleopathological and historic-medical study started in 2004, which is based on the exhumation and analysis of the skeletal remains of the Medici Family buried in the Medici Chapels of Florence. Twelve out of the 21 exhumed individuals were in a state of preservation which permitted to undergo CT and ortopantomography. Pathologic findings were organized in malformations, diffuse parodontopathy, caries, inflammations, and intra-vitam missing teeth.

Dental lesion index (DLI), that is the percentage ratio of the number of damaged teeth out of the total number of examined alveoli, was calculated in all subjects, as absolute value (given as percentage value) as well as age corrected, and compared with DLI of contemporary Aragon family.

Results: Results are arranged for single individuals and for groups of age. The study has shown that all the adults had evident problems in their oral cavities, with values of average age-corrected DLI of 39.27 (males), 41.16 (females) and 39.84 (overall).

Conclusions: The presented data show that the Medici Family suffered from poor dental health, despite the use of mouthwashes and other "hygienic tools", and that their DLI was largely worse than the contemporary Aragon, probably protected by the diet and particularly by fluorine assumed with waters. (c) 2013 Elsevier Ltd. All rights reserved.
\end{abstract}

\section{Introduction}

Despite modern ideas to the contrary, people in the past did spend time trying to take care of their teeth and combat bad breath, above all in upper classes of society, as the dietary reconstruction from buccal dental microwear confirms [1]. According to the literary sources and archive documents, teeth were cleaned by rubbing them with a sort of dentifrice, using toothpicks, and rinsing the mouth with scented mouthwashes [2]. In the Renaissance, the members of the Medici Family, for instance, were accustomed to rinse the mouth with a special good smelling water used as medical treatment. The archive records confirm the use of a particular mouth-wash, named

\footnotetext{
Abbreviations: DLI, Dental lesion index

* Correspondence to: University of Florence, Department of Clinical Physiopathology, Section of Radiodiagnostics, Azienda Ospedaliero-Universitaria Careggi, Largo Brambilla 3, 50141 Florence, Italy.

Tel.: +39055 4377673; fax: +39055 431970 .

E-mail address: stefano.colagrande@unifi.it (S. Colagrande).
}

"Acqua da denti", which consisted in a hydro-alcoholic solution of cloves and guaiac (lignum vitae), scented with anise essential oil, which was believed to be very helpful, as sovereigns of all Europe were looking forward to having it. Francesco I de' Medici, for instance, sent very often to King Felipe II of Spain this "Acqua da denti" with detailed instructions for its use: there was a particular kind of it, called "perfetta", which had to be prepared only in April. Along with many prescriptions of the time, a particular treatment involved the use of vinegar, mixed to mint and left to steep all winter; then, the vinegar was poured off and used to rinse the mouth. The acidic nature of the vinegar might have discouraged some bacteria, and the mint flavour would have refreshed the mouth, helping also in cases of gum sores and gum diseases. Rosemary charcoal was also used: the rosemary is somewhat antiseptic and the charcoal inside increased the abrasiveness, temporarily changing the $\mathrm{pH}$ of the mouth [3]. It is very difficult to check the real effectiveness of these methods, as there are not many series of Renaissance mummies studied in detail by computer assisted tomography (CT) and dental X-rays, as ortopantomography (OPT) [4]. Many members 
of the Medici Family were exhumed in the frame of the Medici project, a paleopathological and historic-medical research performed between 2004 and 2007, on the remains of the members of the Medici Family, who are buried in the Church of San Lorenzo (Florence). The aim of this prospective study is to present the radiological assessment, together with dental lesion index (DLI), of the dental pathologies in the Medici Family in order to supply evidence of their oral diseases and to verify the efficacy of mouthwashes and hygiene methods of the time, providing a term of comparison for other cases [5]. At the same time, a comparison will be done between the Medici and the Aragon Family, who ruled Naples and the Southern part of Italy in the same period: their corpses are buried in the Church of San Domenico Maggiore, in Naples, and they were exhumed and studied few years ago [4].

\section{Materials and methods}

\subsection{Subjects}

From 2004 up to 2007, in the frame of the Medici Project, 21 individuals were exhumed. However, only 12 out of 21 individuals, whose anagraphic data are reported (Table 1), underwent paleopathological and radiological investigation.

\subsection{Imaging}

The 12 subjects were examined by Computed Tomography (CT) and Ortopantomography (OPT), having blocked the upper and lower jaws. CT studies were performed using a Somatom Plus 4 (Siemens, Erlangen, Germany) single slice scanner. Slice thickness was $3 \mathrm{~mm}$, pitch 1 . The other scanning parameters were: matrix $512 \times 512$ pixels, KV $120, \mathrm{~mA} / \mathrm{s} 140$. OPT were acquired by a Siemens device: KV 70, mA/s 15, scanning time $15 \mathrm{~s}$.

\subsection{Image analysis}

On the basis of anamnesis, collected by a medical historian, the revision and comparison of the anatomical remains were provided by a paleopathologist, a dentistry and two radiologists. Pathologic findings were organized as follows: malformations, diffuse parodontopathy, crown and/or interdental caries, inflammations (periradicular inflammation of the root, apical granulomas, pericoronaritis), abscesses, and intra-vitam missing teeth. Presence and grading of diffuse parodontopathy was organized as follows [5]:

Mild (1): rounding and flattening of interdental ridges with decreased bone density and irregular profile.

Intermediate (2): appearance of focal or generalized osteolysis of the bone with gaps in the profile of the ridges.

Serious (3): massive reduction of the bone mass with loss of dental elements and rarefaction/lysis around the roots of the remaining teeth.

Results are given for single individuals (Table 1), and for groups of age (Table 2).

\subsection{Dental lesion index}

The dental lesion index (DLI), that is the percentage ratio of the number of damaged teeth (lost intra vitam, carious and/or affected by abscesses) out of the total number of examined alveoli, was calculated in all subjects (absolute DLI, as percentage value). However, the average based on these indices involves some variations due to death's age, since the number of pathologies usually increases with growing old. Therefore, only of-age individuals (10 out of 12) were considered for the comparison with available series, according to Bisel's formula [6], which gives a linear curve with the equation:

$Y=0.48399514+(0.58206327) X$

where $X$ is the difference between standard (40.875) and individual age (40.875 - age). Then

$Y=0.48399514+(0.58206327)(40.875-$ age $)$

Calculated $Y$ value is to add $(+\mid-)$ from the same individual DLI (age corrected DLI, that is $=\mathrm{DLI}+Y$ ). Finally, we provide the average DLI for each sex separately and together (Table 3).

\section{Results}

Analytical results for every individual are given in Table 1, while the synthesis for groups of age ( $\leq 29$-year-old; 30-59-yearold; $\geq 60$-year-old) are reported in Table 2 .

From the congenital point of view, our data show very clearly the third class jaw (progenism) of Giovanna of Austria (Fig. 1) and the asymmetry of Cardinal Carlo's mandible, probably due to a Klippel Feil's syndrome and other concomitant pathologies (Fig. 2). The most important and frequent acquired pathologies are represented by crown and interdental caries, inflammations, abscesses and parodontopathy in all subjects. It is then well demonstrable (Table 2) that parodontopathy and carious focuses began to occur starting from the twenties (Cardinal Giovanni $\dagger 19$ and Francesco son of Ferdinando $\dagger 20$ ), became serious in the middle age (Eleonora of Toledo $\uparrow 40$, Francesco I †46, Cosimo I †55) (Fig. 3), while the most aged members were completely edentulous (Ferdinando I $\uparrow 60$, Cristina of Lorrain †61, Cardinal Carlo †71, and Gian Gastone †68) (Fig. 4). The analysis of DLI demonstrates a value of 39.27 in males, 41.16 in females, and 39.84 taken as a whole (Table 3 ).

\section{Discussion}

Characteristics related to the sex and the age of the deceased are considered first, two key elements for placing individuals in the funerary complex and in the society from which they derive. The age of the deceased is established from indicators of dental and skeletal maturity for immature individuals: health of teeth moreover is considered a key element to detect the state of general health of an individual and his/her habits of life.

The first observation we have done on the Medici series regards the congenital problems affecting the jaws of Giovanna of Austria and Cardinal Carlo. As far as Giovanna is concerned, it is possible to state that she suffered from the so called Habsburg jaw [7], an anatomical defect which consists in a progenism, that is a prognatism of the mandible (Table 1). From the iconographic sources regarding the dynasty, it seems that the deformity developed and increased with aging and sometimes it was so serious as to have inhibited talking and eating (Fig. 1). Up to now, however, it was only possible to evaluate this malformation in the portraits. It is the first time that paleopathological evidence of this deformity is provided. Moreover, another element must be underlined: it is generally affirmed that this kind of prognatism is transmitted as an autosomal dominant trait and that males are more severely affected than females [8]. The case of Giovanna of Austria, whose portraits show an improvement of her features thanks to the generosity of the painter, provides a positive proof that females suffered from this problem, as well.

Regarding Cardinal Carlo's mandible, the asymmetry of his nasal and maxillary bones, which appear larger on the left side, was already observed, together with the marked hypoplasia of the right hemi-mandible corpus and the right ramus (Table 1) (Fig. 2). These defects of Carlo's facial skeleton and its evident asymmetry, together with the diffused multifactorial ankylosis are supposed to have 


\begin{tabular}{|c|c|c|c|}
\hline \multirow{2}{*}{$\begin{array}{l}\text { Name, code, life period } \\
\text { Cosimo I, Med } 6 \text { (1519-1574) }\end{array}$} & \multicolumn{3}{|l|}{ Findings } \\
\hline & $\begin{array}{l}\text { Malformations: no } \\
\text { Present teeth: } 29 \\
\text { Without/with pathology: } 24 / 5 \\
\text { Various: upper three incisors with worn and brok }\end{array}$ & $\begin{array}{l}\text { Diffuse parodont.: grade II } \\
\text { Lost intra-vitam: } 3 \\
\text { Caries: } 4 \\
\text { en crowns }\end{array}$ & Inflammation ( \pm caries): 1 \\
\hline Eleonora of Toledo, Med 5 (1522-1562) & $\begin{array}{l}\text { Malformations: no } \\
\text { Present teeth: } 23 \\
\text { Without/with pathology: } 18 / 5 \\
\text { Various: incisors with worn crowns }\end{array}$ & $\begin{array}{l}\text { Diffuse parodont.: grade III } \\
\text { Lost intra-vitam: } 9 \\
\text { Caries: } 4\end{array}$ & Inflammation ( \pm caries): 1 \\
\hline Cardinal Giovanni, Med 3 (1543-1562) & $\begin{array}{l}\text { Malformations: no } \\
\text { Present teeth: } 32 \\
\text { Without/with pathology: } 30 / 2 \\
\text { Various: incisors with worn crowns. Pericoronarit }\end{array}$ & $\begin{array}{l}\text { Diffuse parodont.: grade I } \\
\text { Lost intra-vitam: } 0 \\
\text { Caries: } 0 \\
\text { is in included lower left third }\end{array}$ & $\begin{array}{l}\text { Inflammation ( } \pm \text { caries): } 2 \\
\text { molar }\end{array}$ \\
\hline Don Garcia, Med 4 (1547-1562) & $\begin{array}{l}\text { Malformations: no } \\
\text { Present teeth: } 29 \\
\text { Without/with pathology: } 30 / 0 \\
\text { Various: upper left first premolar lost post morten } \\
\text { mesioverted osseous inclusion resting on the post }\end{array}$ & $\begin{array}{l}\text { Diffuse parodont.: grade I } \\
\text { Lost intra-vitam: } 1 \\
\text { Caries: } 0 \\
\text { m, found in the skull. Lower ri } \\
\text { erior root of the adjacent seco }\end{array}$ & $\begin{array}{l}\text { Inflammation ( } \pm \text { caries): } 0 \\
\text { ight/left third molar: in full } \\
\text { nd molars. }\end{array}$ \\
\hline Francesco I, Med 11 (1541-1587) & $\begin{array}{l}\text { Malformations: no } \\
\text { Present teeth: } 26 \\
\text { Without/with pathology: } 26 / 0 \\
\text { Various: lower right second molar and lower left }\end{array}$ & $\begin{array}{l}\text { Diffuse parodont:: grade III } \\
\text { Lost intra-vitam: } 6 \\
\text { Caries: } 0 \\
\text { first and second molar with hc }\end{array}$ & $\begin{array}{l}\text { Inflammation ( } \pm \text { caries): } 0 \\
\text { look roots }\end{array}$ \\
\hline Giovanna of Austria, Med 8 (1547-1578) & $\begin{array}{l}\text { Malformations: Hasburg's jaw } \\
\text { Present teeth: } 32 \\
\text { Without/with pathology: } 32 / 0 \\
\text { Various: lower right/left second molar and upper } \\
\text { lower right-left first molar and lower right second }\end{array}$ & $\begin{array}{l}\text { Diffuse parodont:: grade II } \\
\text { Lost intra-vitam: } 0 \\
\text { Caries: } 0 \\
\text { right second premolar (disodo } \\
\text { premolar (hook roots). }\end{array}$ & $\begin{array}{l}\text { Inflammation ( } \pm \text { caries): } 0 \\
\text { ontiasis with mesioversion); }\end{array}$ \\
\hline Princess Anna, Med 10 (1569-1583) & $\begin{array}{l}\text { Malformations: no } \\
\text { Present teeth: } 28 \\
\text { Without/with pathology: } 28 / 0 \\
\text { Various: no acquired pathologic alterations; upper } \\
\text { second premolar, root dismorphism. }\end{array}$ & $\begin{array}{l}\text { Diffuse parodont:: no } \\
\text { Lost intra-vitam: } 0 \\
\text { Caries: } 0 \\
\text { r/lower right/left molars, not y }\end{array}$ & $\begin{array}{l}\text { Inflammation ( } \pm \text { caries): } 0 \\
\text { yet erupted; lower right/left }\end{array}$ \\
\hline Ferdinando I, Med 12 (1549-1609) & $\begin{array}{l}\text { Malformations: no } \\
\text { Present teeth: } 23 \\
\text { Without/with pathology: } 15 / 8 \\
\text { Various: osteoporosis of the jaw }\end{array}$ & $\begin{array}{l}\text { Diffuse parodont.: grade III } \\
\text { Lost intra-vitam: } 9 \\
\text { Caries: } 2\end{array}$ & Inflammation ( \pm caries $): 6$ \\
\hline Cristina of Lorrain, Med 21 (1565-1636) & $\begin{array}{l}\text { Malformations: mandibular condyles dismorphic } \\
\text { Present teeth: } 1 \\
\text { Without/with pathology: } 1 / 0 \\
\text { Various: unerupted lower right third molar entirel } \\
\text { reactive periradicular manifestations due to absces }\end{array}$ & $\begin{array}{l}\text { Diffuse parodont.: grade III } \\
\text { Lost intra-vitam: } 31 \\
\text { Caries: } 0 \\
\text { ly bone included. Lower left thi } \\
\text { ssual focus. }\end{array}$ & $\begin{array}{l}\text { Inflammation ( } \pm \text { caries }) \text { : } 0 \\
\text { ird molar, lost intra-vitam with }\end{array}$ \\
\hline Cardinal Carlo, Med 29 (1595-1666) & $\begin{array}{l}\text { Malformations: dismorphic right emi-mandible a } \\
\text { Diffuse parodont.: grade III } \\
\text { Present teeth: } 7 \\
\text { Without/with pathology: } 2 / 5 \\
\text { Various: severe osteoporosis of the jaw }\end{array}$ & $\begin{array}{l}\text { And condyle smaller than the } \mathrm{c} \\
\text { Lost intra-vitam: } 25 \\
\text { Caries: } 1\end{array}$ & $\begin{array}{l}\text { Inflammation ( } \pm \text { caries): } 4 \\
\text { counter lateral. }\end{array}$ \\
\hline Francesco son of Ferdinando I, Med 13 (1594-1614) & $\begin{array}{l}\text { Malformations: no } \\
\text { Present teeth: } 32 \\
\text { Without/with pathology: } 29 / 3 \\
\text { Various:- }\end{array}$ & $\begin{array}{l}\text { Diffuse parodont:: grade II } \\
\text { Lost intra-vitam: } 0 \\
\text { Caries: } 3\end{array}$ & Inflammation( \pm caries $): 0$ \\
\hline Gian Gastone, Med 40 (1671-1737) & $\begin{array}{l}\text { Malformations: no } \\
\text { Present teeth: } 0 \\
\text { Without/with pathology: } 0 / 0 \\
\text { Various: severe osteoporosis of the jaw }\end{array}$ & $\begin{array}{l}\text { Diffuse parodont.: grade III } \\
\text { Lost intra-vitam: } 32 \\
\text { Caries: } 0\end{array}$ & Inflammation ( \pm caries): 0 \\
\hline
\end{tabular}

Paradont. $=$ paradontopathy

greatly worsened the quality of the last years of life of Cardinal Carlo, who was forced to bed and ate with great difficulties [9].

Some interesting observations regard acquired pathologies, as summarized in tables (Tables 1 and 2) and below explained.

Notwithstanding the attempts used by the members of the Medici family to preserve their teeth, our paleopathological investigation has demonstrated that even people of the high classes of society suffered from decay toothaches, diffuse parodontopathy and premature teeth loss, as it was noted also in other cultural contexts [10-12]. The studies on the masticatory apparatus, obtained using imaging studies, allow us to confirm that many of the acquired pathologies were due to a lack of oral hygiene. The high style of life of these august people, which was characterized by rich meals, caused a constant presence of food remains in the interdental space; this is usually the primum movens of dental plaque, the first stage of caries, which may have 
Table 2

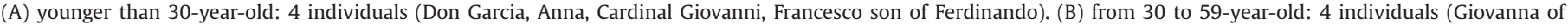

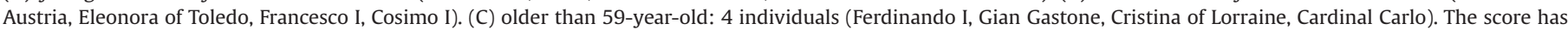
been evaluated by the sum of the grade of parodontopathy of the single individual.

\begin{tabular}{|c|c|c|c|c|}
\hline & $<30(128)^{\mathrm{a}}$ & $30-59(128)^{b}$ & $\geq 59(128)^{c}$ & Overall (384) \\
\hline Intra-vitam lost & $1(0.78 \%)$ & $18(14.06 \%)$ & $97(75.78 \%)$ & $116(30.20 \%)$ \\
\hline Diseased (carried \pm inflammation) & $5(3.90 \%)$ & $10(7.80 \%)$ & $13(10.15 \%)$ & $28(7.29 \%)$ \\
\hline Tot. lost plus diseased & $6(4.68 \%)$ & $28(21.87 \%)$ & $110(85.93 \%)$ & $144(37.50 \%)$ \\
\hline Parodontopathy score and (mean) ${ }^{\mathrm{d}}$ & $4(1)$ & $10(2.5)$ & $12(3)$ & $26(2.16)$ \\
\hline
\end{tabular}

a $\leq$ 30-year-old: 4 individuals (Don Garcia, Anna, Cardinal Giovanni, Francesco son of Ferdinando).

b 30-59-year-old: 4 individuals (Giovanna of Austria, Eleonora of Toledo, Francesco I, Cosimo I).

c $\geq$ 59-year-old: 4 individuals (Ferdinando I, Gian Gastone, Cristina of Lorraine, Cardinal Carlo).

${ }^{\mathrm{d}}$ The score has been evaluated by the sum of the grade of parodontopathy of the single individual.

Table 3

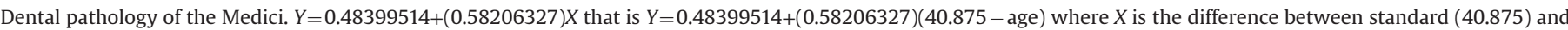
individual age. Calculated $Y$ value is to add $(+\mid-)$ to the same individual DLI.

\begin{tabular}{|c|c|c|c|c|c|c|c|c|}
\hline Name & $\begin{array}{l}\text { Teeth missing } \\
\text { intra-vitam }\end{array}$ & Caries & Inflammation \pm caries & $\begin{array}{l}\text { Teeth } \\
\text { diseased }\end{array}$ & $\begin{array}{l}\text { Teeth missing } \\
\text { iv+diseased }\end{array}$ & $\begin{array}{l}\text { DLI absolute (teeth missing } \\
+ \text { diseased } / 32 \times 100=\% \text { ) }\end{array}$ & $\begin{array}{l}X \\
(40.87-\text { age })\end{array}$ & $\begin{array}{l}\text { DLI age corrected } \\
\text { (that is }=D L I+Y)\end{array}$ \\
\hline Cosimo I aged 55 & 3 & 4 & 1 & 5 & 8 & $8 / 32=25 \%$ & -14.13 & 16.77 \\
\hline $\begin{array}{l}\text { Eleonora of Toledo } \\
\text { aged } 40\end{array}$ & 9 & 4 & 1 & 5 & 14 & $14 / 32=43.7 \%$ & 0.88 & 44.65 \\
\hline $\begin{array}{l}\text { Cardinale Giovanni } \\
\text { aged } 19\end{array}$ & $\mathbf{0}$ & $\mathbf{0}$ & 2 & 2 & 2 & $2 / 32=6.25 \%$ & 21.88 & 19.47 \\
\hline Francesco I age 46 & 6 & $\mathbf{0}$ & $\mathbf{0}$ & $\mathbf{0}$ & 6 & $6 / 32=18 \%$ & -5.13 & 14.53 \\
\hline $\begin{array}{l}\text { Giovanna of Austria } \\
\text { aged } 31\end{array}$ & $\mathbf{0}$ & $\mathbf{0}$ & $\mathbf{0}$ & $\mathbf{0}$ & $\mathbf{0}$ & $0 / 32=0 \%$ & 9.88 & $\mathbf{0}$ \\
\hline Ferdinando I aged 60 & 9 & 2 & 6 & 8 & 17 & $17 / 32=53.12 \%$ & -19.13 & 41.50 \\
\hline $\begin{array}{l}\text { Cristina of } \\
\text { Lorrainaged } 71\end{array}$ & 31 & $\mathbf{0}$ & $\mathbf{0}$ & $\mathbf{0}$ & 31 & $31 / 32=96.87 \%$ & -30.13 & 78.85 \\
\hline $\begin{array}{l}\text { Cardinale Carlo aged } \\
71\end{array}$ & 25 & 1 & 4 & 5 & 30 & $30 / 32=93.75 \%$ & -30.13 & 75.73 \\
\hline $\begin{array}{l}\text { Francesco son of } \\
\text { Ferdinando aged } 20\end{array}$ & $\mathbf{0}$ & 3 & $\mathbf{0}$ & 3 & 3 & $3 / 32=9.37 \%$ & 20.88 & 22.00 \\
\hline Gian Gastone aged 66 & 32 & $\mathbf{0}$ & $\mathbf{0}$ & $\mathbf{0}$ & 32 & $32 / 32=100 \%$ & -25.13 & 84.89 \\
\hline $\begin{array}{l}\text { Total } \\
\text { Males (7)/Females (3) }\end{array}$ & 116 & 14 & 14 & 28 & 144 & & & $\begin{array}{l}39.84 \\
39.27 / 41.16\end{array}$ \\
\hline
\end{tabular}

led to the loss of teeth through parodontopathy, periradicular flogosis, dental abscesses $[13,14]$. This is well demonstrable by the analysis of the four youngest people, aged from 14 to 20, who show a mean stage 1 of parodontopathy, which becomes particularly severe with aging: as a matter of fact, the four people aged over 60 demonstrate the presence of a stage 3 (Table 2) (Figs. 3 and 4). Analyzing attrition and other dental affections, it can be observed that in some cases, on the half arches of maxillary and mandible's teeth, artificial grooves were probably caused by the insertion of a tooth-pick among the teeth for cleaning. Tooth loss and big atrophy of tissues occur in most cases, as consequence of inflammatory parodontopathy and caries, thus being very probably caused by the dietary customs, too. Moreover in the case of women, it is highly possible that the frequent pregnancies may also have caused a deterioration of teeth (Eleonora of Toledo), tooth mobility and tooth loss.

Nowadays, common dental indices used in oral health surveys include Decayed-Missing-Filled Teeth index, an irreversible index used to measure past and present caries in a population with permanent teeth, and Root Caries Index. The latter should be a practical index for reporting root caries data in epidemiologic studies as well as assessing the results of preventive/treatment agents. The Root Caries Index represents, in the evolution of a root caries measurement method, a refinement of the delineation of the true intraoral "population at risk" to the disease process.

A more precise study of the state of dental health can be obtained using the DLI, in particular age corrected (Table 3). We have preferred to use the DLI in order to better compare our data with the results of a similar research performed on the teeth belonging to the members of the Aragonese Family. In fact, long-term intake of excessive amounts of bio-available fluoride causes skeletal and dental changes, referred to as fluorosis. The fluoride-induced dental changes are known as dental fluorosis and reflect an impairment of the processes involved in the formation of the dental hard tissues. The macroscopic alterations visible in fluorotic teeth are a consequence of the disturbance of enamel formation. In both humans and other mammals, dental fluorosis has been used as a biomarker of elevated fluoride exposure. Cases of endemic fluorosis have been reported world-wide in human and animal populations; due to either high natural background-levels of fluoride or to fluoride released from anthropogenic sources.

The possibility to study in detail the original data regarding the Medici Family and to compare them with other analogous cases, dating back to the same period and belonging to the same social milieu, in particular with the Aragon series, was particularly interesting.

This comparison reveals overall age corrected DLI of 39.84 of the Medici vs. 22.53 of the Aragon, and consequently severe dental 
A

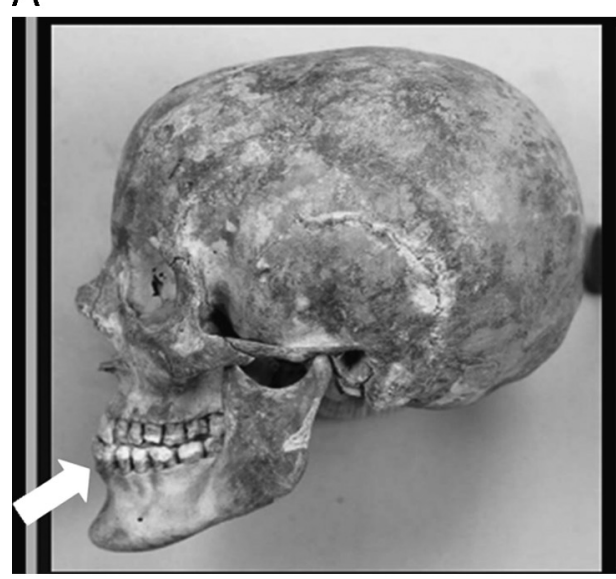

C
B

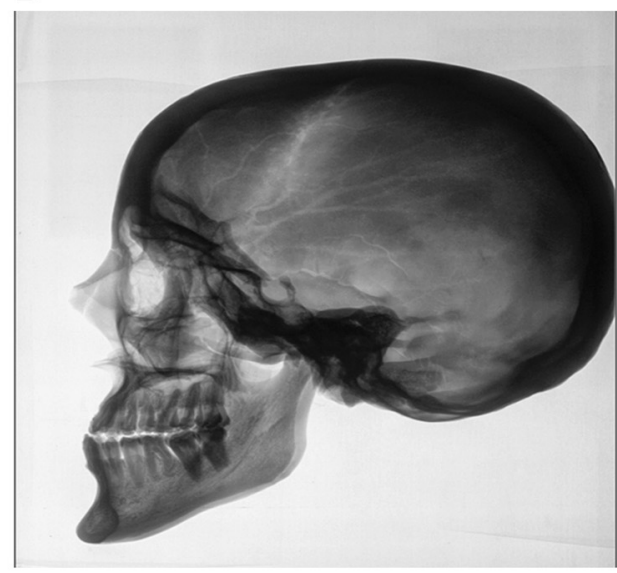

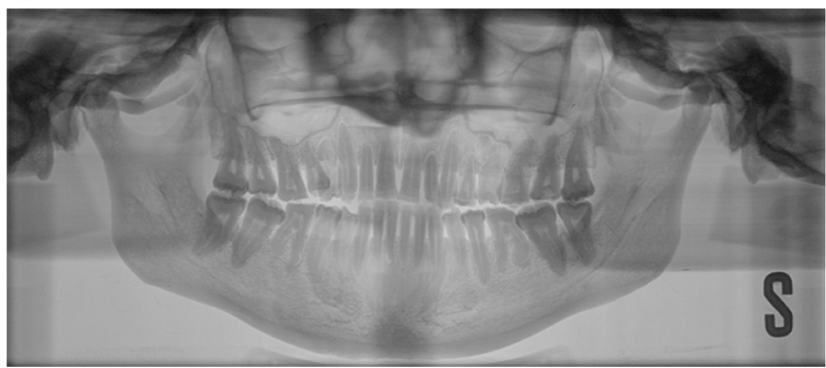

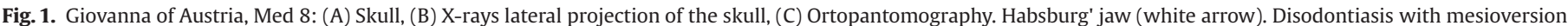
of the lower right/left second molar and upper right second premolar. Hook roots of the lower right-left first molar and lower right second premolar.

pathology and worse dental health. Nowadays, this kind of pathology and its severity in contemporary western populations is linked with food rich in proteins and sugar, as honey, which in the Renaissance was typical of wealthy classes. Historical records reveal that the Medici had a great use of meat and wine, which constituted the central nucleus of their diet, which was mainly based on high protein substances. Eggs and cheese also were consumed, even not so frequently: they were combined with meat on normal days and alternated with fish on penitential occasions. Documents confirm that in the Medici's diet, vegetables occupied a secondary place, with almost total absence of fruit, which was used to prepare cakes and beverages. The use of a very sophisticated cooking may have had severe consequences on their oral health, too $[15,16]$. These data were confirmed by the paleo-nutritional study performed on their remains. The results were compared with the outcomes of a similar research, carried on the remains of the contemporary Aragon Princes in Naples (15th-17th centuries). That study demonstrated that carbon and nitrogen stable isotope analysis of bone collagen showed high values of nitrogen at the level of carnivores, proving that the diet of the Medici was very rich in meat. Carbon values were in accordance with an intake of fish, especially for the Aragon series, which can be estimated at $14-30 \%$ for the Medici and $12-40 \%$ for the Aragon. This variation in intake is important but it is not enough to completely explain the very different state of dental health between the two dynasties, nor could the methods of oral hygiene used by the Aragons be so helpful to avoid cariogenic process. These data strongly suggest the presence of environmental circumstances, which could have determined these conditions: as a matter of fact, it was already noted in the past that people living close to Naples suffered from endemic dental fluorosis [17-20]. Studies carried out in some Italian regions some years ago have demonstrated that the Community Fluorosis Index for all permanent teeth is significantly higher in high- fluoride area, 0.8, than the value, 0.1, found in the low-fluoride community, determining the necessity to defluoridate and fluoridate the water supplies in areas with drinking water naturally containing above-optimal ( $\geq 2.5 \mathrm{mg} / \mathrm{l}$ ) and suboptimal ( $\leq 0.3 \mathrm{mg} / \mathrm{l}$ ) fluoride concentration [21].

As known, fluoride catalyzes the diffusion of calcium and phosphate into the tooth surface, which in turn remineralizes the crystalline structures in a dental cavity. The remineralized tooth surfaces contain fluoridated hydroxyapatite and fluorapatite, which resist acid attack much better than the original tooth did [22-25].

Besides the use of waters rich in fluorine, however, it is possible to suppose that the teeth of the Aragon were constitutionally less receptive to cariogenic factors. In fact, three factors (the epidemiological triad) play a role in the development of dental caries: the host (genetic predisposition, malnutrition during teeth formation and behaviour, such as dietary habits and oral hygiene practices); the agent (mainly Streptococcus mutans); and finally the environment (lack of fluoride in water, lack of vitamin D and high consumption of refined sugars). The interaction of these factors with cultural, genetic, geographic and/or environmental variations may have determined the differences observed.

As the matter of fact, the analysis of the teeth of present-day patients from Tuscany shows a lower enamel fluorine concentration with respect to ancient inhabitants of Naples [20]. Interestingly, no significant difference was found between male/female DLI in the Medici Family (39.27 and 41.16, respectively), whilst in the Aragon Family an important disparity should be noted (20.34 and 27.29, respectively). The worse DLI showed by the Aragon women can be easily explained by the frequent pregnancies. Perhaps, this difference male/female is not so evident in the Medici Family, due to the very bad dental status of the male 
A

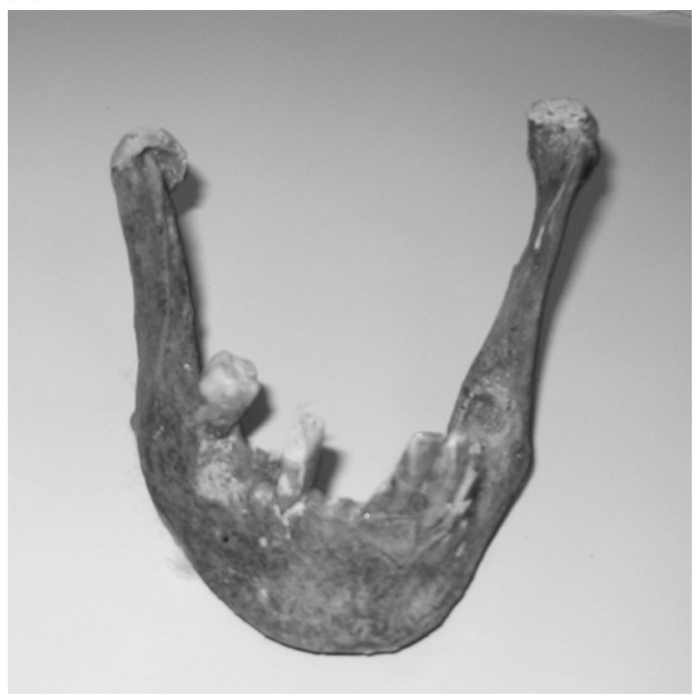

B

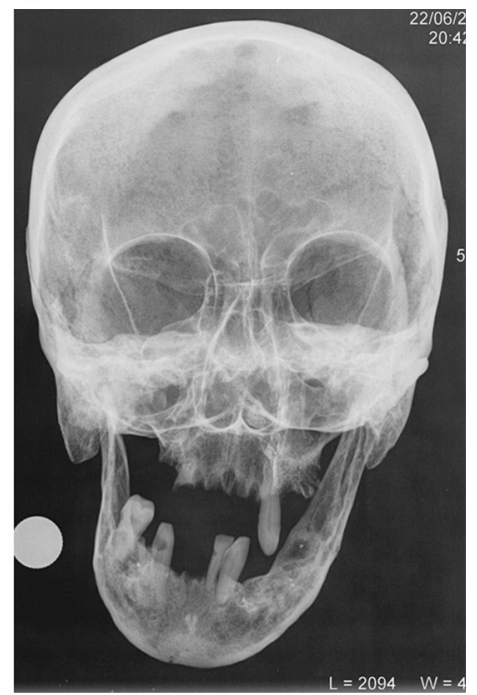

C

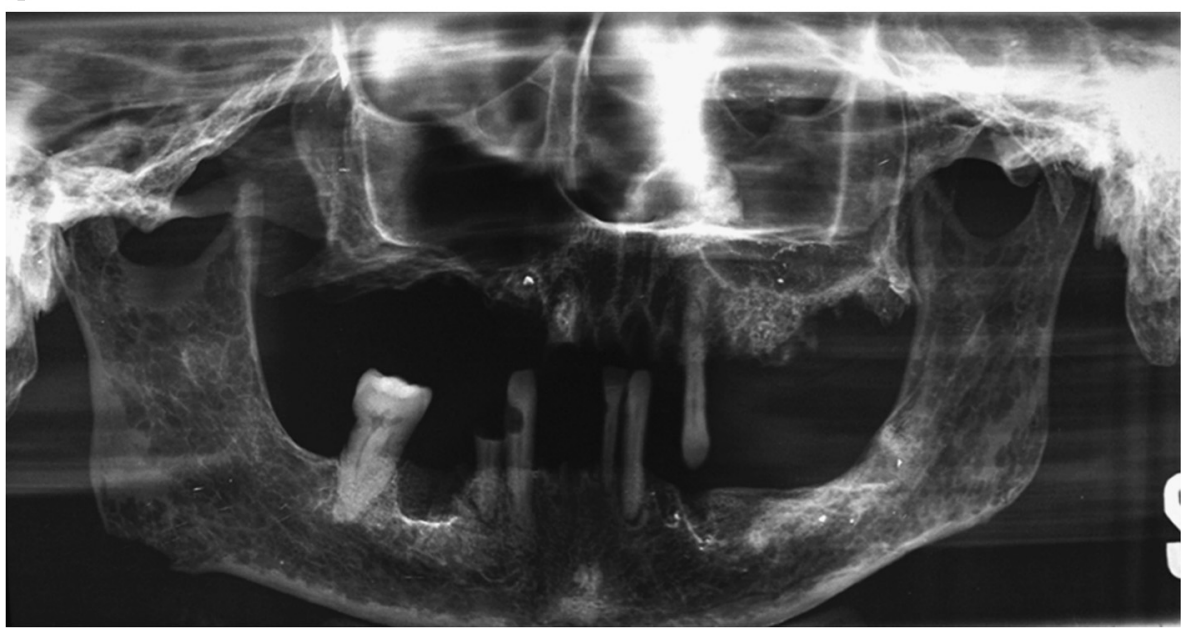

$\mathrm{D}$

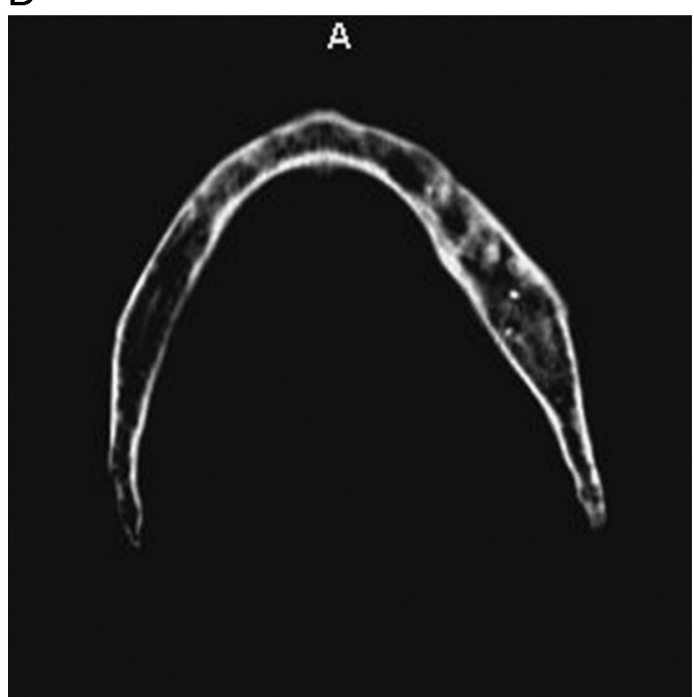

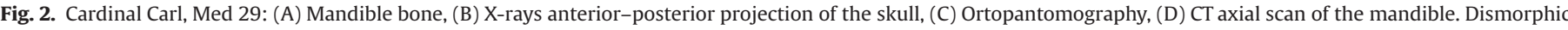

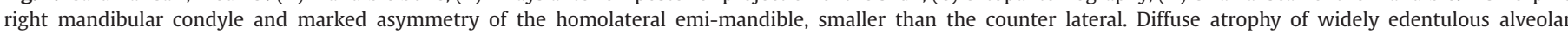

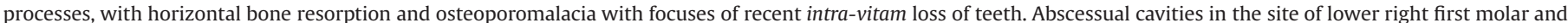
lower left third molar. 
A

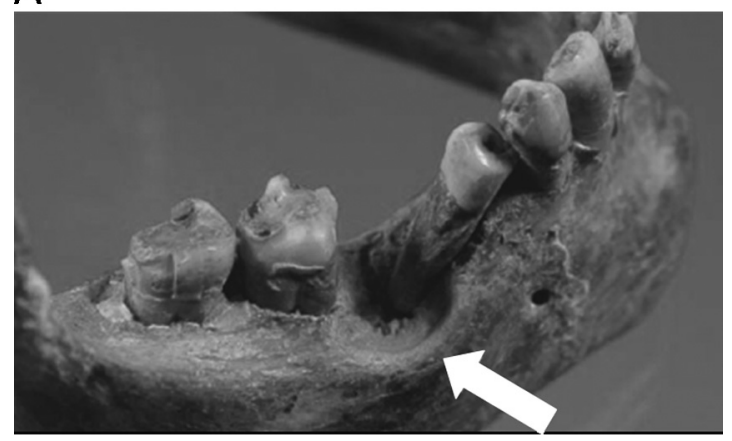

B

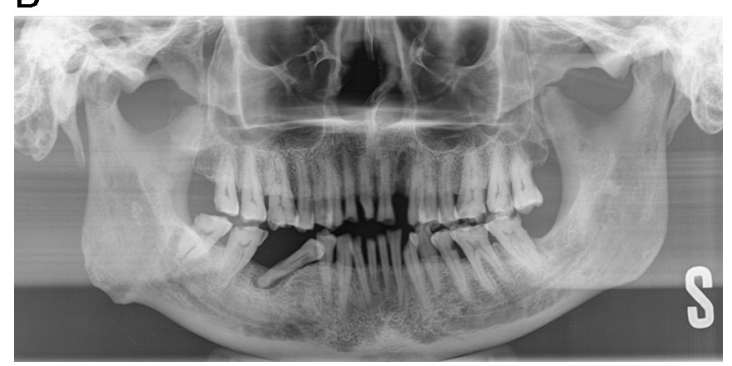

Fig. 3. Cosimo I, Med 6: (A) Mandible bone, (B) Ortopantomography. Diffuse signs of parodontopathy. Crown caries of the lower right third molar and lower left second molar. Interdental caries focuses of the lower left second premolar. Periradicular inflammation of the root of the upper right second incisor. Abscess of the lower right second premolar (mesioverted - white arrow). Worn and broken crowns of the upper three incisors. Upper left second incisor, lower right first molar, lower right first premolar, lower left third molar: missing intra-vitam.

members as well, which probably led to an equalization toward the lowest DLI values. However, the numbers are scarce (only 3 women in our series) and then without a valuable statistical strength (Table 4).

\section{Conclusion}

Dental fluorosis can be used as a retrospective biomarker of fluoride exposure during the period of tooth formation. Increased exposure to fluoride after the permanent dentition has been fully formed will not result in the fluorotic enamel changes that are responsible for the macroscopically visible alterations in the affected teeth. This means that prevalence and severity of dental fluorosis reflect fluoride exposure. The weak but significant positive correlation between DLI and age is ascribed to the fact that continuous use of fluorotic teeth with reduced enamel hardness leads to increasing tooth damage.

The presented data show that the Medici Family suffered from poor dental health, despite the use of mouthwashes and other "hygienic tools", with a DLI largely worse than the contemporary Aragon, protected by the diet and particularly by fluoride that the rulers of Naples assumed with waters.

\section{Acknowledgements}

The authors are very grateful to the "Soprintendenza Speciale del Polo Museale Fiorentino" for the use of the materials (Medici Project).

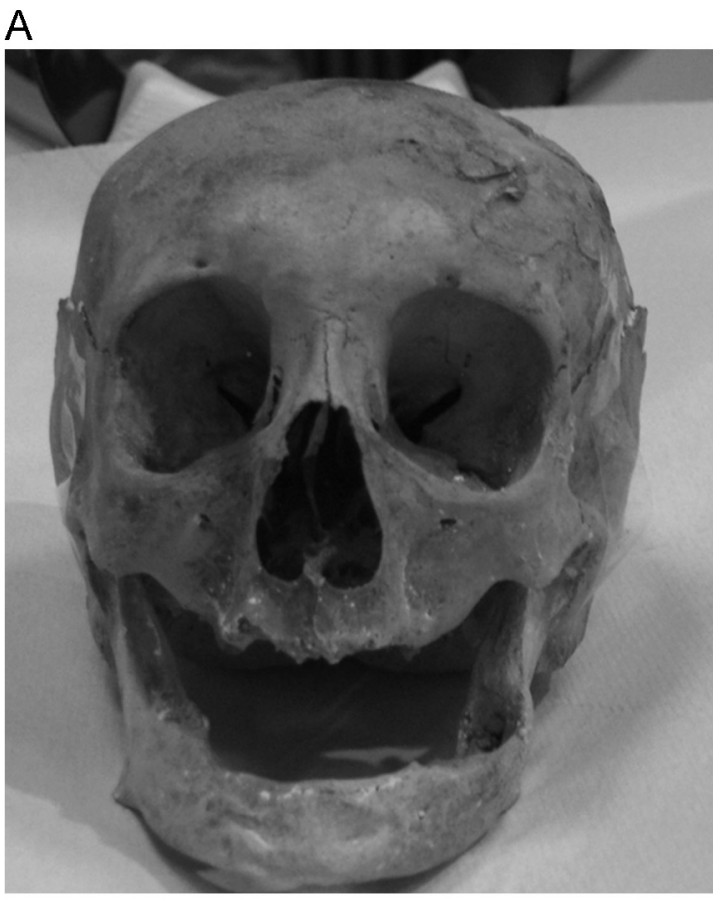

B

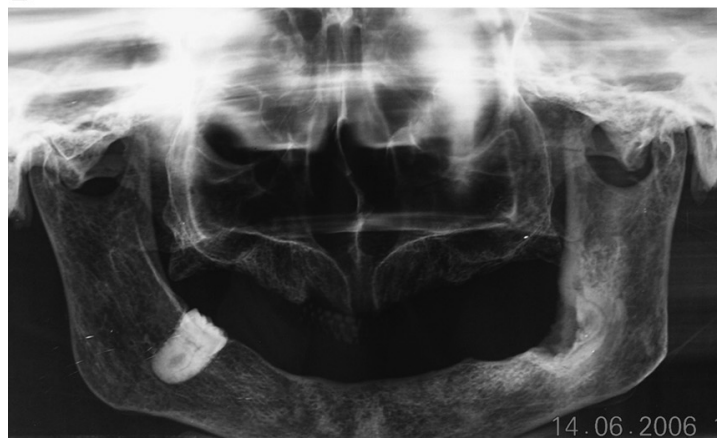

Fig. 4. Cristina di Lorena, Med 21: (A) Skull, (B) Ortopantomography. Upper and lower arch entirely edentulous, except unerupted lower right third molar, with large bone resorption. Reactive periradicular manifestations due to abscessual focus in the site of the lower left third molar.

Table 4

Dental Lesion Index, age corrected, in the Medici (Florence) and Aragonese series (Naples).

Adult males Adult females Males+females

\begin{tabular}{llll}
\hline Medici (16th-17th centuries) & (7) 39.27 & (3) 41.16 & (10) 39.84 \\
Aragonese (16th-17th centuries) & (13) 20.34 & (6) 27.29 & (19) 22.53 \\
\hline
\end{tabular}

\section{References}

[1] M.L. Powell, The analysis of dental wear and caries for dietary reconstruction, in: R.I. Gilbert, J.H. Mielke (Eds.), The Analysis of Prehistoric Diets, Academic Press, London, 1988, pp. 8307-8738.

[2] D. Lippi, The diseases of the Medici Family and the use of phytotherapy, Evidence-Based Complementary and Alternative Medicine 4 (2007) 9-11.

[3] M. Fornaciari, The Aragonese mummies of the Basilica of Saint Domenico Maggiore in Naples, Medicina nei Secoli 18 (2006) 843-844.

[4] D. Lippi, The Medici Project, Herald of Europe 3 (2006) 122-125.

[5] R. Nessi, L.Viganò, Radiologia odontostomatologica, Piccin, Padova, 2004.

[6] S.L.C. Bisel, A Pilot Study in Aspects of Human Nutrition in the Ancient Eastern Mediterranean with Particular Attention to Trace Minerals in Several Populations 
from Different Time Periods (Ph.D. thesis), Smithsonian Institution, Washington DC, 1980.

[7] D. Lippi, F. Pierleoni, L. Franchi, Retrognathic maxilla in "Habsburg jaw", The Angle Orthodontist 82 (2012) 387-395.

[8] E.M. Thomsson, R.M. Winter, Another family with the 'Habsburg jaw', Journal of Medical Genetics 25 (1988) 838-842.

[9] V. Giuffra, A. Vitiello, S. Giusiani et alii, Rheumatoid artritis, Klippel-Feil syndrome and Pott's disease in Cardinal Carlo de' Medici (1595-1666), Clinical and Experimental Rheumatology 27 (2009) 594-602.

[10] D. Biow, The Culture of Cleanliness in Reinassance Italy, Cornell University Press, Ithaca, N.Y., and London, 2006.

[11] M.D. Grmek, Diseases in the Ancient Greek World, The John Hopkins University Press, Baltimore and London, 1989.

[12] V.O. Hurme, Relation of dental caries to health history, physical measurements, and heredity, Journal of Dental Research 15 (1935) 395-396.

[13] A.J. Grieco, Food and social classes in late Medieval and Renaissance Italy, in: J. L. Flandrin, M. Montanari (Eds.), Food. A Culinary History from Antiquity to the Present, Columbia University Press, New York, 1999, pp. 302-312.

[14] M.A Katzenberg, Stable isotope analysis: a tool for studying past diet, demography and life history, in: M.A. Katzenberg, S.R Saunders (Eds.), Biological Anthropology of the Human Skeleton, Wiley-Liss, New York, 2000, pp. 305-327.

[15] G. Fornaciari, Food and disease at the Renaissance courts of Naples and Florence: a paleonutritional study, Appetite 51 (2008) 10-14.
[16] K. Whitaker, How do dental studies contribute to the reconstruction of the live of past peoples? EAA Summer School eBook 1 (2007) 27-33.

[17] M. Torino, M. Rognoni, G. Fornaciari, Dental fluorosis in ancient Herculaneum, The Lancet 345 (1995) 1306.

[18] J.M. Eager, Denti di Chiaie (Chiaie teeth), Public Health Reports 16 (1901) 25-76.

[19] G. Fornaciari, G.M. Brogi, M.G. Balducci, Dental pathology of the skeletal remains of Pontecagnano, Salerno-Italy: VII-IV centuries B.C., Ossa 12 (1985) 9-31.

[20] G. Fornaciari, G. Brogi, A. Menconi, L. Pollina, Dental pathology of a wealthy class of Italian Renaissance: the mummies of the Abbey of S. Domenico Maggiore in Naples (XVI century), Journal of Paleopathology Monographic Publications 1 (1989) 57-58.

[21] I.F. Angelillo, I. Torre, C.G. Nobile, P. Villari, Caries and fluorosis prevalence in communities with different concentrations of fluoride in the water, Caries Research 33 (1999) 114-122.

[22] Z. Mandinic, M. Curcic, B. Antonijevic et alii, Fluoride in drinking water and dental fluorosis, Science Total Environment 408 (2010) 3507-3512.

[23] E. Newbrun, What we know and do not know about fluoride, Journal Public Health Dentistry 70 (2010) 227-233.

[24] J.A. Alvarez, K.M. Rezende, S.M. Marocho, F.B. Alves, P. Celiberti, A.L. Ciamponi Dental fluorosis: exposure, prevention and management, Medicina Oral, Patologia Oral y Cirurgia Bucal 14 (2009) 103-107.

[25] F.J. Mac Clure, R.C. Likins, Fluorine in human teeth studied in relation to fluorine in the drinking water, Journal of Dental Research 30 (1951) 172. 